\title{
Review of William B. Parsons's Freud and Augustine in Dialogue
}

\author{
Katie Givens Kime
}

Published online: 14 January 2015

(C) Springer Science+Business Media New York 2015

The title of William B. Parsons's (2013) Freud and Augustine in Dialogue: Psychoanalysis, Mysticism, and the Culture of Modern Spirituality is somewhat misleading. Do not expect any conjured cozy chats between these two giants of Western thought. Parsons does not seek to collapse the enormous historical distance between eras. Rather, one can expect a trustworthy, needed, formidable addition to psychoanalytic readings of the mystical elements of Augustine's Confessions. This book emerges from decades of solid scholarship that has been mapping the contours of what Parsons calls the psychology-and-religion movement (which includes the classic psychology of religion approach, the dialogue between psychology and theology, psychospirituality, and the psychology-comparativist dialogue), as well as serious and informed engagement with the ontological claims of mystical experience. Parsons's central claim is that Augustine's visions are at the core of his religious journey. He seeks to model "how a mystical work such as the Confessions can be reread and allowed to speak anew to psychoanalysis and a therapy-absorbed culture currently informed by a revived interest in things mystical" (Parsons 2013, p. 23).

Looking back, perhaps the only surprise is that it took modern psychoanalysis until 1957 to start snatching at the low-hanging fruit in Confessions. The theft of the pears, the bath episode, the beatings at school, the nature of Augustine's relationship with the nameless concubine, the erotically tinged relationship with his mother, and the notable absence of his father-so many elements of Confessions seem psychoanalytically ripe for the picking. About the (arguably) best and first psychologist in the ancient Western world, Parsons asks, "What are we to make of Augustine's insistence that his personal experience led him to conclude that there is a 'stomach to the mind,' that 'what is inside the mind is mostly hidden'? Or that there exists a 'sad kind of darkness' that circumvents the mind's ability to enlighten itself?" (p. 10). After a thorough review of psychoanalytic studies of Confessions (which are preoccupied with the pre-Oedipal nature of Augustine's narrative), Parsons insists that not only can we not credibly psychoanalyze the historical Augustine apart from the construction of his narrative, but we fail to appreciate what is arguably most pertinent to the changing landscape of psychoanalysis and of Western religiosity in general: the visions of Augustine the mystic.

Historically, Parsons argues, the Freudian architecture of psychoanalysis explains the neglect of mysticism in psychoanalytic studies of Confessions (and elsewhere). Moreover,

K. G. Kime $(\bowtie)$

Graduate Division of Religion, Emory University, S214 Callaway Memorial Center, 537 Kilgo Circle,

Atlanta, GA 30322, USA

e-mail: kgkime@gmail.com 
the history of psychoanalysis gives evidence why-despite Freud's firm and notorious rejection of religion, his avowed atheism, and his arch reductionism - notions of spirituality bubble up in modern psychoanalytic practice and theory.

Most scholars, clinicians, and practitioners of pastoral psychology will agree with Parsons that its origin may be traced to the time period of 1880-1944. In the rich and generative half century preceding World War I, some people experienced Christian theology and academic psychology as splitting like divergent rivers, while others saw an opportunity for the birth of new paradigms like the American hospital chaplaincy movement and clinical pastoral education. Parsons proposes, based on the work of William James, Henri Delacroix, Frederic Myers and others, that interest in mysticism during this period was widespread, with the glaring exception of the author of psychoanalysis, Sigmund Freud. Freud's "suspicion of religious orthodoxy, and the construal of religion in psychological and therapeutic terms," Parsons maintains, ironically contributed much to the rise of modern spirituality. "The methodological perspectives on and insights into the human personality Freud bequeathed us have, even against his wishes, played an instrumental role in the cultural ascendency and personal orientation of those professing to be spiritual but not religious" (p. 2). Now, psychoanalysis, long regarded as the most hostile enemy of Western religiosity, finds itself engaging spiritual concerns on a number of fronts. "Spirituality has crept into the practice of psychoanalysts, into the therapeutic expectations of analysands, and even into psychoanalytic theory itself" (p. 11). Thus, for Parsons, the time has arrived for fresh engagements of Augustinian mysticism and Freudian psychoanalysis.

One set of insights particularly valued by this reader revolves around the engagement of Freud's take on mystical intuition beyond his notorious (and scant) "oceanic feeling" discourses. Not only do previous decades of Freudian theorizing on mysticism misread and misrepresent the texts and letters that constitute Freud's correspondence with Romain Rolland-i.e., "all mysticism is but a regression to the developmental stage of primary narcissism" (p. 50) - they also neglect a fascinating strand of Freud's thinking. Parsons explores the lesser noted Group Psychology and the Analysis of the Ego, in which Freud expands upon "the wider sense" of his use of the term Eros, noting how Plato's conception of the term "coincides exactly with the love-force, the libido of psychoanalysis," as does that of the apostle Paul in Corinthians, for when "he praises love above all else, he certainly understands it in the same "wider sense"" (p. 71). Some 13 months before his death, Freud returned again to what Parsons calls his "emerging model of mystical ecstasy and intuition," noting that "mysticism is the obscure self-perception of the realm outside the ego, of the id" (as cited on p. 82), meaning that the motivations of religious ecstasy are universal memory traces of our transmitted heritage. From these fresh angles, Parsons weaves new insights from Confessions without departing from the work's identity as an ancient text situated "in its textual, theological, socio-historical, and literary contexts" (p. 129).

Turning a psychoanalytic gaze on Augustine's visions, Parsons notes one of many shared goals and insights between Augustine and Freud: "The problem for Augustine was the inability of humans to sustain vision .. . the thrust of Confessions is precisely to deny the permanence of vision. In this, Augustine was like Freud, who initially thought cures were possible, only to conclude later that analysis was interminable"” (p. 105). Moreover, for Parsons, a faithful reading of Augustine's mysticism (and Christian mysticism in general), per Bernard McGinn, is as a process and a way of life. Such a reading of mystic experience is to be distinguished from mysticism as James tended to frame it, which was as episodic, ecstatic encounters with the divine. A process view of mysticism evokes psychological conceptions of development and transformation of character. 
Beyond mother problems, Augustine's interpretation of his ecstatic visions in Confessions contributes to what psychoanalysis knows about "the long transformative struggle of analysands in psychoanalytic therapy [that] cannot be reduced to the episodic, to a singular insight or epiphany, even though such events unquestionably occur and often mark important moments in the course of a successful therapy" (p. 103). Parsons also proposes that Augustine and psychoanalysis agree on the value of the talking cure, with its emphasis on self-disclosure and confession. Furthermore, Augustine's therapeia shares "the psychoanalytic goal of unearthing unconscious content" (p. 132) in his dogged efforts to discern his own depths.

Parsons is careful to disclaim several potential misinterpretations of this study; "the aim is not to expand psychoanalytic thought to fully tally with Augustine's mystical theology" but instead to "open up new lines of argument . . . where the two introspective traditions might have more to talk about than has previously been acknowledged" (p. 69). This is the way in which Parsons's work is a dialogue. When psychoanalysis engages Confessions constructively (rather than reductively or symptomatically), it has much to illuminate about the process of human transformation. Similarly, Augustine's articulation of mysticism, properly understood, has much to offer the Freudian "wider sense" of the psychoanalytic process.

Vague terms abound, but Parsons addresses the challenges. He rightly notes that "mysticism" suffers major definitional problems, not unlike other terms such as "spirituality," "mystical theology," and "modern spirituality." In fact, Parsons notes that "how these terms are defined and unpacked, and how that unpacking plays out with regard to psychoanalytic inquiry and to the argument presented here, is a central concern of this book" (p. 8).

The only quibble of this reader is a minor one. The "culture of modern spirituality" and the "ascendant cultural milieu" (p. 133), which Parsons claims are most evident in the growing numbers of those who identify themselves as "spiritual but not religious," beg more elaboration. Parsons is quick - and correct - to note how, within the finite bounds of this single book, he cannot possibly attend to all the "complex origins and interactions of the multiple cultural strands and eddies that have collaborated in the rise of a psychologically informed modern spirituality" (p. 133). Still, I was left wanting more definition, or at least a summary of the ocean of recent scholarship on those professing to be "spiritual but not religious."

Freud's friend Rolland maintained that engagement with the unconscious is a critical piece to understanding the aspects of mystical consciousness, quipping that mystics " "did not wait for Dr. Freud to teach them that the best cure for the mind is to make it look at its deeply hidden monsters straight in the face"” (p. 105). Similarly, Freudians have not waited - and are not waiting - for mystics to tell them that transformation cannot be reduced to the episodic. Nevertheless, for those of us who bathe and thrash about in the waters of both mystical insight and psychoanalytic insight, Parsons's subtle, responsible, and important work is a gift.

\section{Reference}

Parsons, W. (2013). Freud and Augustine in dialogue: Psychoanalysis, mysticism, and the culture of modern spirituality. Charlottesville: University of Virginia Press. 